\title{
Pengaruh Pemberian Susu Coklat Terhadap Kadar F2- Isoprostan pada Siswa di Pusat Pendidikan dan Latihan Olahraga Pelajar (PPLP) Sumatera Barat
}

Dezi Ilham ${ }^{1}$, Afriwardi² $^{2}$ Eti Yerizel ${ }^{3}$

\begin{abstract}
Abstrak
Latihan fisik yang berlebihan dapat meningkatkan produksi radikal bebas di dalam tubuh. Peningkatan radikal bebas ini kalau tidak dinetralisasi oleh antioksidan di dalam tubuh, maka terjadilah stres oksidatif yang dapat menyebabkan terjadinya peroksidasi lipid, sehingga menghasilkan produk senyawa F2-isoprostan yang dapat berdampak terhadap berbagai masalah kesehatan. Tujuan penelitian ini adalah untuk menentukan pengaruh pemberian susu coklat terhadap kadar F2-isoprostan. Penelitian ini merupakan eksperimental pre and post test control grup design terhadap 36 siswa atlet, yang memenuhi kriteria inklusi dan ekslusi. Subjek dibagi dua kelompok yaitu yang diberikan perlakuan susu coklat dan kontrol susu putih. Susu diminum setelah latihan fisik rutin atlet sebanyak satu kali sehari selama 15 hari. Kadar F2-isoprostan dinilai sebelum dan sesudah secara ELISA. Data dianalisis dengan paired sample $t$-Test, bermakna bila $\mathrm{p}<0,05$. Hasil penelitian didapatkan rerata kadar F2-isoprostan sebelum perlakuan pada kelompok susu coklat adalah $65,98 \pm 14,61 \mathrm{pg} / \mathrm{ml}$ dan sesudah perlakuan adalah 45,55 $\pm 13,74 \mathrm{pg} / \mathrm{ml}$. Rerata kadar F2-isoprostan sebelum perlakuan pada kelompok kontrol susu putih adalah $54,24 \pm 20,44 \mathrm{pg} / \mathrm{ml}$ dan sesudah perlakuan adalah 48,80 $\pm 20,23 \mathrm{pg} / \mathrm{ml}$. Kesimpulan yang diperoleh ada pengaruh yang bermakna dari rerata kadar F2-isoprostan sebelum dan sesudah perlakuan baik pada kelompok perlakuan susu coklat dan kelompok kontrol susu putih.
\end{abstract}

Kata kunci: latihan fisik, radikal bebas, F2-isoprostan, susu coklat

\begin{abstract}
Excessive physical exercise can increase the production of free radicals in the body. The increase in free radicals if not neutralized by antioxidants in the body and it caused oxidative stress which can cause lipid peroxidation, resulting in F2-isoprostane product compounds that can affect a variety of health problems. The objective of this study was to determine the influence of milk chocolate on F2-isoprostane levels. This study was an experimental pre and post test control group design to the 36 student athletes, who meet the inclusion and exclusion criteria. The subjects were divided in two groups: the treatment given milk chocolate and white milk is given control, drunk after a routine physical exercise athlete, once a day for 15 days. F2-isoprostane levels were assessed before (pre) and after (post) by ELISA, the data were analyzed by Paired Sample $t$-Test, significant if $p<0.05$. The results showed average levels of F2-isoprostane before treatment group was $65.98 \pm$ chocolate milk $14.61 \mathrm{pg} / \mathrm{ml}$ and after treatment was $45.55 \pm$ $13.74 \mathrm{pg} / \mathrm{ml}$. Average F2-isoprostane levels before treatment in the control group was $54.24 \pm$ white milk $20.44 \mathrm{pg} /$ $\mathrm{ml}$ and after treatment was $48.80 \pm 20.23 \mathrm{pg} / \mathrm{ml}$. There is a significant influence on the mean levels of F2-isoprostane both before and after treatment in the treatment group and the control group of milk chocolate and white milk
\end{abstract}

Keywords: physical exercise, free radicals, f2-isoprostane, milk chocolate

Affiliasi penulis: 1. Program Studi S2 Magister Biomedik FK UNAND (Fakultas Kedokteran Universitas Andalas Padang), 2. Bagian Fisiologi FK UNAND, 3. Bagian Biokimia FK UNAND
Korespondensi: Dezi Ilham, E-mail : dezi.fkunand@gmail.com,Telp: 082390817339 


\section{PENDAHULUAN}

Olahraga adalah aktifitas fisik yang merupakan sarana pelatihan untuk memelihara, meningkatkan derajat kesehatan dan kualitas hidup untuk menuju kondisi sejahtera paripurna sesuai konsep sehat dari WHO (World Health Organization). Olahraga membina mutu sumber daya manusia melalui pendekatan aspek jasmaniah. ${ }^{1} \mathrm{Hal}$ ini menyebabkan perubahan dinamik seperti perubahan anatomik dan fisiologik, juga perubahan pada tingkat biologi seluler, bahkan pada tingkat biologi molekuler. ${ }^{2}$ Olahraga merupakan aktifitas sistem musculoskeletal yang sistematik dan terstruktur dengan frekwensi, intensitas, tipe dan waktu yang telah ditentukan. ${ }^{3}$

Olahraga yang dilakukan untuk tujuan manfaat kebugaran tubuh dapat dilakukan tiga kali dalam seminggu, baik pada olahraga prestasi maupun olahraga kesehatan. Lamanya durasi waktu latihan yang dapat dilakukan antara 20-30 menit dalam zona latihan tersebut. Hal ini disebabkan karena ketahanan tubuh seseorang akan menurun jika tidak melakukan latihan kembali dalam kurun waktu 48 jam. Jadi, diusahakan sebelum ketahanan menurun harus sudah berlatih lagi. Pada saat latihan atau menghadapi suatu pertandingan/kejuaraan para atlit sering kali melakukan latihan yang melebihi takaran latihan yang tidak dianjurkan. ${ }^{4}$

Latihan yang berlebihan merupakan suatu tanda dari durasi latihan yang lama, intesitas latihan yang berat dan waktu latihan yang sering. Pada latihan ini dapat menimbulkan atau memicu ketidakseimbangan antara produksi radikal bebas dengan antioksidan dalam tubuh. Molekul radikal bebas ini sangat reaktif dan bila berlebihan menyebabkan kerusakan terhadap dinding sel endotel pembuluh darah dan akhirnya menyebabkan timbulnya berbagai penyakit kronis, kerusakan otot dan penurunan fungsi kekebalan tubuh, sehingga dapat mempengaruhi kinerja dari latihan. ${ }^{5}$ Peningkatan jumlah radikal bebas yang melebihi kemampuan sistem pertahanan tubuh dan kalau tidak dapat dinetralisasi oleh antioksidan dalam tubuh maka terjadilah stres oksidatif, sehingga dapat menyebabkan kerusakan pada lemak dan asam arakidonat. ${ }^{6}$

Asam arakidonat merupakan asam lemak tidak jenuh, yang sumber utamanya berasal dari asupan asam linoleat dan berada dalam tubuh dalam bentuk esterifikasi sebagai komponen fosfolipid membran sel. Asam arakidonat sangat mudah dirusak oleh radikal bebas. Jika produksi radikal bebas didalam tubuh sangat tinggi dapat menyebabkan terjadinya peroksidasi asam arakidonat oleh radikal bebas, sehingga akan menghasilkan suatu senyawa F2isoprostan. ${ }^{7}$ F2-isoprostan merupakan standar emas sebagai hasil ukur dari kerusakan stres oksidatif. Secara kimiawi F2-Isoprostan bersifat lebih stabil, dapat terdeteksi pada semua jaringan dan cairan biologis tubuh. ${ }^{8}$

Fase pemulihan merupakan fase yang penting pada setelah latihan olahraga karena pada fase ini terjadi proses pemulihan bagi fungsi asal biologis tubuh menjadi seperti kondisi semula/sebelum latihan. ${ }^{9}$ Beberapa cara untuk mengurangi radikal bebas yang timbul akibat aktivitas fisik yang berlebihan antara lain dengan pemberian antioksidan. Antioksidan adalah senyawa yang mampu menangkal atau meredam dampak negatif oksidan dalam tubuh. ${ }^{10}$ Antioksidan termasuk enzim - enzim dan protein protein pengikat logam bekerja dengan cara mendonorkan satu elektronnya kepada senyawa yang bersifat oksidan sehingga aktivitas senyawa oksidan tersebut dihambat. ${ }^{11}$

Beberapa penelitian menyebutkan susu coklat adalah minuman yang bermanfaat dan paling potensial bagi atlit untuk fase pemulihan setelah melakukan aktifitas olahraga dan juga mengandung sumber antioksidan. ${ }^{12}$ Kandungan antioksidan pada coklat sangat tinggi yaitu flavonoid yang merupakan senyawa turunan dari polifenol. Manfaat kandungan yang terdapat dalam susu sangat membantu memulihkan kembali energi dan jaringan otot yang telah digunakan saat melakukan latihan fisik. Sedangkan manfaat antioksidan yang terkandung pada coklat dapat membantu meredam efek buruk kerusakan yang ditimbulkan oleh radikal bebas. ${ }^{13}$

\section{METODE}

Jenis penelitian yang digunakan adalah eksperimental yang menggunakan desain penelitian Pre and Post-test control group design. ${ }^{14}$ Yaitu rancangan yang digunakan untuk mengukur pengaruh perlakuan pada kelompok eksperimen tersebut 
dengan cara membandingkannya terhadap kelompok kontrol. Penelitian dilakukan terhadap 36 orang subjek penelitian yang terdiri dari 2 kelompok, yaitu kelompok yang diberikan perlakuan susu coklat dan kelompok yang diberikan susu putih (kontrol). Pada Kelompok perlakuan susu coklat berisi minuman susu sapi murni $250 \mathrm{ml}$ dengan bubuk coklat $20 \mathrm{gr}$. Sedangkan kelompok kontrol susu putih berisi hanya minuman susu sapi murni $250 \mathrm{ml}$. Perlakuan minuman susu ini diberikan pada saat fase pemulihan atlet, setelah melakukan latihan rutin setiap sore sebanyak 1 kali sehari selama 15 hari.

\section{HASIL}

Penelitian ini dilakukan terhadap siswa atlet di PPLP Sumbar dan pemeriksaan kadar serum f2isoprostan dilakukan di Laboratorium Biomedik Fakultas Kedokteran Unand. Waktu dalam penelitian ini dimulai dari bulan November 2013 - April 2015. Hasil dari pengukuran terhadap kadar F2-isoprostan tersebut dapat dilihat pada tabel berikut ini:

Tabel 1. Rerata kadar F2-isoprostan sebelum perlakuan

\begin{tabular}{lccc}
\hline Kelompok & N & Rerata \pm SD & P \\
\hline susu coklat & 18 & $65,98 \pm 14,61$ & 0.056 \\
susu putih & 18 & $54,24 \pm 20,44$ & \\
\hline
\end{tabular}

Berdasarkan Tabel 1 didapatkan rerata kadar F2-isoprostan sebelum perlakuan pada kelompok susu coklat $65,98 \pm 14,61 \mathrm{pg} / \mathrm{ml}$ dan kelompok kontrol susu putih 54,24 $\pm 20,44 \mathrm{pg} / \mathrm{ml}$. Dari hasil uji statistik tidak terdapat perbedaan yang signifikan $\mathrm{P}>0,05$.

Tabel 2. Rerata kadar F2-isoprostan sesudah perlakuan

\begin{tabular}{lccc}
\hline Kelompok & N & Rerata \pm SD & P \\
\hline susu coklat & 18 & $45,55 \pm 13,74$ & 0.577 \\
susu putih & 18 & $48,80 \pm 20,23$ & \\
\hline
\end{tabular}

Berdasarkan Tabel 2 didapatkan rerata kadar F2-isoprostan sesudah perlakuan pada kelompok susu coklat 45,55 $\pm 13,74 \mathrm{pg} / \mathrm{ml}$ dan kelompok kontrol susu putih $48,80 \pm 20,23 \mathrm{pg} / \mathrm{ml}$. Dari hasil uji statistik tidak terdapat perbedaan yang signifikan $\mathrm{P}>0,05$.
Tabel 3. Rerata kadar F2-isoprostan sebelum dan sesudah perlakuan pada kelompok susu coklat

\begin{tabular}{lccc}
\hline Perlakuan & N & Rerata \pm SD & p \\
\hline Sebelum & 18 & $65,98 \pm 14,61$ & 0.000 \\
Sesudah & 18 & $45,55 \pm 13,74$ & \\
\hline
\end{tabular}

Berdasarkan Tabel 3 didapatkan rerata kadar F2-isoprostan sebelum perlakuan pada kelompok susu coklat $65,98 \pm 14,61 \mathrm{pg} / \mathrm{ml}$ dan sesudah perlakuan $45,55 \pm 13,74 \mathrm{pg} / \mathrm{ml}$. Dari hasil uji statistik terdapat perbedaan yang signifikan $\mathrm{P}<0,05$.

Tabel 4. Rerata kadar f2-isoprostan sebelum dan sesudah perlakuan pada kelompok kontrol susu putih

\begin{tabular}{lccc}
\hline Perlakuan & N & Rerata \pm SD & p \\
\hline Sebelum & 18 & $54,24 \pm 20,44$ & 0.000 \\
Sesudah & 18 & $48,80 \pm 20,23$ & \\
\hline
\end{tabular}

Berdasarkan Tabel 4 didapatkan rerata kadar F2-isoprostan sebelum perlakuan pada kelompok kontrol susu putih $54,24 \pm 20,44 \mathrm{pg} / \mathrm{ml}$ dan sesudah perlakuan 48,80 $\pm 20,23 \mathrm{pg} / \mathrm{ml}$. Dari hasil uji statistic terdapat perbedaan yang signifikan $\mathrm{P}<0,05$.

Tabel 5. Rerata selisih kadar F2-isoprostan antara kelompok perlakuan susu coklat dengan kelompok kontrol susu putih

\begin{tabular}{lccc}
\hline Kelompok & N & Rerata \pm SD & p \\
\hline Susu Coklat & 18 & $20,42 \pm 6,67$ & \multirow{2}{*}{0.000} \\
Susu Putih & 18 & $5,43 \pm 2,98$ & \\
\hline
\end{tabular}

Berdasarkan Tabel 5 didapatkan rerata selisih kadar F2-isoprostan pada kelompok perlakuan susu coklat $20,42 \pm 6,67 \mathrm{pg} / \mathrm{ml}$ dan rerata selisih pada kelompok kontrol susu putih 5,43 $\pm 2,98 \mathrm{pg} / \mathrm{ml}$. Hasil uji statistik terdapat perbedaan yang signifikan $\mathrm{P}<0,05$.

\section{PEMBAHASAN}

Hasil penelitian didapatkan rerata kadar F2isoprostan sebelum perlakuan pada kelompok susu coklat adalah $65,98 \mathrm{pg} / \mathrm{ml}$ dan sebelum perlakuan pada kelompok kontrol susu putih adalah 54,24 pg/ml. Rerata kadar F2-isoprostan sesudah perlakuan pada kelompok susu coklat adalah 45,55 pg/ml dan sesudah perlakuan pada kelompok kontrol susu putih 
adalah 48,80 pg/ml. Dari hasil uji statistik tidak terdapat perbedaan yang signifikan rerata kadar f2isoprostan baik pada kelompok sebelum perlakuan (pre) maupun kelompok sesudah perlakuan (post).

Hal ini juga diperkuat oleh penelitian yang dilakukan Block pada tahun 2002, yang melakukan penelitian multivarian terhadap status stres oksidatif dengan menggunakan marker F2-isoprostan. Variabelvariable yang diperiksa dalam penelitian tersebut meliputi jenis kelamin, usia, ras, berat badan, status merokok, kadar nikotin plasma; kadar antioksidan plasma seperti carotenoid, $\alpha$ - dan $\mathrm{y}$-tocopherol dan asam askorbat; kadar lemak plasma meliputi kolesterol serum dan trigliserida; C-reaktif protein dan kadar saturasi transferrin. Hasil penelitian tersebut didapatkan kadar plasma asam askorbat yang memiliki hubungan terbalik secara konsisten dengan kadar F2-isoprostan, yaitu semakin tinggi kadar asam askorbat maka akan semakin rendah kadar F2isoprostan. Kadar plasma asam askorbat merupakan antioksidan yang dapat mempengaruhi status stress oksidatif yang tentu saja mempengaruhi kadar F2isoprostan pada saat pengambilan darah sampel. ${ }^{15}$

Hasil rerata kadar F2-isoprostan sebelum dan sesudah perlakuan didapatkan hasil rerata kadar F2isoprostan sebelum perlakuan pada kelompok susu coklat adalah $65,98 \mathrm{pg} / \mathrm{ml}$ dan sesudah perlakuan adalah 45,55 pg/ml. Hasil rerata kadar F2-isoprostan sebelum perlakuan pada kelompok kontrol susu putih adalah $54,24 \mathrm{pg} / \mathrm{ml}$ dan sesudah perlakuan adalah $48,80 \mathrm{pg} / \mathrm{ml}$. Ada pengaruh yang signifikan terhadap penurunan kadar F2-isoprostan sebelum dan sesudah perlakuan, baik pada kelompok perlakuan susu coklat dan kelompok kontrol susu putih dengan nilai $p(0,000)$ atau $<0,05$.

Perbedaan rerata selisih kadar F2-isoprostan, didapatkan perbedaan yang signifikan antara kelompok perlakuan susu coklat dengan kelompok kontrol susu putih dengan nilai $p(0,000)$ atau $<0,05$. Dimana rerata selisih kadar F2-isoprostan pada kelompok susu coklat adalah 20,42 pg/ml dan rerata selisih kadar F2-isoprostan pada kelompok kontrol susu putih adalah 5,43 pg/ml. Hal ini menunjukan bahwa dengan pemberian minuman susu coklat pada saat fase pemulihan atlet, memberikan manfaat hasil pemulihan yang maksimal dari pada atlet yang diberikan pemulihan kontrol minuman susu putih. Hal ini juga dapat dijelaskan bahwa kandungan antioksidan dari senyawa polifenol yang terdapat pada susu coklat menunjukkan menghambat proses peroksidasi lipid yang terjadi pada membran sel yang ditunjukkan dengan terjadinya penurunan rerata selisih kadar F2-isoprostan secara signifikan pada atlet yang diberikan minuman susu coklat dibandingkan dengan atlet yang diberikan perlakuan kontrol minuman susu putih. ${ }^{16}$

Peningkatan F2-isoprostan ini terjadi karena aktivitas fisik yang berlebihan sehingga meningkatkan kontraksi kerja pada otot sehingga laju metabolisme dan suhu juga meningkat. Peningkatan suhu dan laju metabolisme tubuh ini akan mengakibatkan peningkatan pemakaian oksigen di jaringan, karena oksigen yang berkurang sehingga menyebabkan terjadi peningkatan pembentukan radikal bebas. ${ }^{17}$ Peningkatan radikal bebas akan menimbulkan kerusakan terhadap membran sel. Dimana jumlah radikal bebas yang terbentuk akan setara dengan proses peroksidasi lemak yang terjadi di membran sel yang dapat dinilai dengan pembentukan senyawa F2isoprostan. ${ }^{18}$

Susu coklat merupakan minuman pemulihan yang memberikan manfaat yang paling optimal dalam pasca latihan. Minuman susu coklat diperlukan untuk atlet daya tahan tinggi, dibandingkan dengan minuman susu biasa, air atau kebanyakan minuman olahraga lainnya. Minuman susu coklat memiliki tambahan dua kali lipat karbohidrat dan protein konten sempurna untuk mengisi otot yang lelah dan membantu memulihkan kembali energi. ${ }^{19}$ Kadar air yang tinggi pada susu coklat dapat menggantikan cairan yang hilang sebagai keringat dan mencegah dehidrasi. ${ }^{20}$ Sedangkan antioksidan yang terdapat pada kandungan susu coklat, membantu mencegah atlet dari kerusakan sel dalam melakukan latihan, sehingga minuman pemulihan susu coklat dikatakan memiliki kelebihan dan keunggulan dari pada minuman pemulihan lain seperti susu biasa atau minuman olahraga komersial lainnya.

\section{KESIMPULAN}

Pada penelitian ini dapat disimpulkan bahwa terdapat pengaruh yang bermakna dari rerata kadar 
F2-isoprostan sebelum dan sesudah perlakuan baik pada kelompok perlakuan susu coklat dan kelompok kontrol susu putih.

\section{UCAPAN TERIMA KASIH}

Terima kasih kepada Dinas Pemuda dan Olahraga (DISPORA) dan Pusat Pendidikan dan Latihan Olahraga Pelajar (PPLP) Sumatera Barat yang sudah membantu dalam melaksanakan proses penelitian serta kepada Staf Bagian Laboratorium Biomedik Fakultas Kedokteran Unand yang telah membantu dalam menyelesaikan penelitian ini.

\section{DAFTAR PUSTAKA}

1. Giriwijoyo S. Fungsi tubuh manusia pada olahraga untuk kesehatan dan prestasi. Bandung: PT Remaja Rosdakarya; 2012.

2. Baraas F. Kardiologi molekuler. Jakarta: Grafiti Pers; 2006.

3. Wiarto G. Fisiologi dan olah raga.Yogyakarta: Graha IImu; 2013.

4. Sherwood L. Fisiologi manusia: dari sel ke sistem. Terjemahan. Jakarta:EGC; 2012.

5. Powers S, Jackson M. Exercise-induced oxidative stress: cellular mechanisms and impact on muscle force production. Physiol Rev. 2008;1243-76.

6. Fridén $\mathrm{J}$, Lieber $\mathrm{R}$, Hargreaves $\mathrm{M}$, Urhausen $\mathrm{A}$. Recovery after training-inflammation, metabolism, tissue repair and overtraining. Dalam: Textbook of Sports Medicine Basic Science and Clinical Aspects of Sports Injury and Physical Activity. 2003;189-200.

7. Finstere J. Review biomarkers of peripheral muscle fatigue during exercise. Finsterer BMC Musculoskeletal Disorders. 2012;1-13.

8. Montuschi P, Barnes P, Roberts J. Isoprostanes: markers and mediators of oxidative stress. Faseb J. 2004;171-80.

9. Harjanto. Pemulihan stres oksidatif pada latihan olahraga. Jurnal Kedokteran Yarsi. 2004;(3):81-7.

10. Winarsi W. Antioksidan alami dan radikal bebas.
Yogyakarta: Penerbit Kanisius; 2007.

11. Pangkahila W. Memperlambat penuaan, meningkatkan kualitas hidup. Jakarta: Penerbit Buku Kompas; 2007.

12. Karp JR, Johnston JD, Tecklenburg S, Mickleborough TD, Fly AD, Stager JM. Chocolate milk as a post-exercice recovery aid. J Sport Nutrition Exercise Metabolism. 2006;78-91.

13. Gilson SF, Saunders MJ, Moran CW, Moore RW, Womack CJ, Todd MK. Effect of chocolate milk consumption on makers of muscle recovery following soccer training : a randomized cross-over study. J Int Sport Nutr. 2010;7-19.

14. Sastroamoro S, Ismail S. Dasar-dasar metodologi penelitian klinis. Jakarta: CV Agung Seto; 2002.

15. Block G, Dietrich M, Norkus EP, Morrow JD, Hudes $\mathrm{M}$, Bette $\mathrm{C}$, et al. Factors associated with oxidative stress in human population. American Journal of Epidemiology. 2002:274-85.

16. Cooper C, Vollard N, Choueiri T, Wilson M. Exercise, free radikals and oxidative stress. Biochemical Society Transactio. 2002:280-5.

17. Andrea Y, William T, Myron G, Alma S, William R, Mindy $S$, et al. Aerobic training reduces systemic oxidative stress in young women with elevated levels of F2-isoprostanes. NIH Public Access. 2013;(2):212-7.

18. Martin LJ. Carbohydrates and protein in chocolate milk help muscles recover from exercise. WebMD Health News. 2010;(1):50-62.

19. Gilson SF, Saunders MJ, Moran CW, Moore RW, Womack CJ, Todd MK. Effect of chocolate milk consumption on makers of muscle recovery following soccer training : a randomized cross-over study. J Int Sport Nutr. 2010;7-19.

20. Monagas M, Khan N, Lacueva CA, Casas R, Sarda MU, Llorach R, Raventos RML, Estruch R. Effect of cocoa powder on the modulation of inflammatory biomakers in patients at risk of cardiovaskular disease. Am J Clin Nutr. 2009;1144-50. 